Terbit online pada laman web jurnal: http://jurnal.iaii.or.id

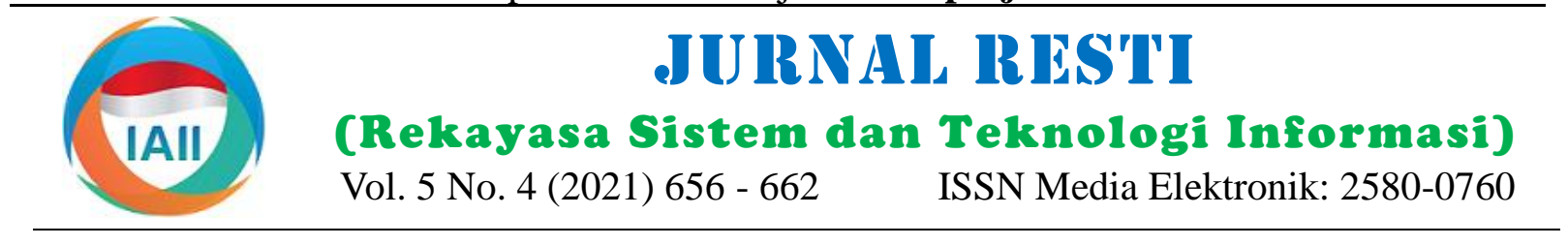

\title{
Klasifikasi Citra Daging Menggunakan Deep Learning dengan Optimisasi Hard Voting
}

\author{
Made Bramasta Vikana Putra ${ }^{1}$, I Putu Agung Bayupati², Dewa Made Sri Arsa ${ }^{3}$ \\ ${ }^{1,2,3}$ Teknologi Infromasi, Fakultas Teknik, Universitas Udayana \\ bramastavikanaputra@gmail.com, ${ }^{2}$ bayupati@unud.ac.id, ${ }^{3}$ dewamsa@unud.ac.id
}

\begin{abstract}
Meat is a staple food for some Indonesian people, apart from the taste, meat also contains vitamins and minerals that are good for the human body, however, not all meat can be consumed by the Indonesian people. the texture and color of beef, pork and mutton have similarities and tend to be similar, therefore a system is needed to recognize the three types of meat. In this study, the authors use various types of Deep Learning architecture such as Resnet-50,VGG-16, VGG-19 and Densenet-121 with Hard Voting to improve the performance of Deep Learning in recognizing the three types of meat. The results show that Resnet50 with Hard Voting can outperform Deep Learning Resnet-50, VGG-16, VGG-19 and Densenet-121- with f1 score 98.88\%, precision $98.89 \%$ and recall $98.88 \%$. in image classification of pork, beef and mutton.
\end{abstract}

Keywords: Deep Leaning, Ensemble Learning, Image Recognition, Transfer Learning

\begin{abstract}
Abstrak
Daging merupakan makanan pokok bagi sebagian masyarakat Indonesia, selain karena cita rasa, daging juga mengandung vitamin dan mineral yang baik untuk tubuh manusia, namun dengan demikian tidak semua daging dapat dikonsumsi oleh masyarakat Indonesia, secara tekstur dan warna daging sapi,daging babi dan daging kambing memiliki kemiripan dan cenderung serupa maka dari itu dibutuhkan sebua sistem mengenali ketiga jenis daging tersebut. Penelitian ini penulis menggunakan berbagai jenis arsitektur Deep Learning seperti Resnet-50, VGG-16, VGG-19 dan Densenet-121 dengan Hard Voting untuk meningkatkan performance dari Deep Learning dalam mengenali ketiga jenis daging tersebut. Hasil penelitian menunjukkan bahwa Resnet-50 dengan Hard Voting dapat mengungguli kemampuan Deep Learning Resnet-50, VGG-16, VGG-19 dan Densenet-121- dengan f1 score 98,88\%, precision $98,89 \%$ dan recall $98,88 \%$ dalam klasifikasi citra daging babi, daging sapi dan daging kambing.
\end{abstract}

Kata kunci: Deep Leaning, Ensemble Learning, Image Recognition, Transfer Learning

\section{Pendahuluan}

Daging merupakan makanan pokok bagi sebagian masyarakat indonesia selain dari aspek rasa, daging juga memiliki banyak kandungan vitamin dan sehingga tidak heran jika daging dapat ditemukan di banyak pasar di Indonesia namun, tidak semua jenis daging dapat di konsumsi oleh masyarakat Indonesia seperti daging babi, hal tersebut mengakibatkan harga daging babi di Deep Learning merupakan pembelajaran representasi Indonesia cenderung lebih murah dibandingakan dengan multilayer dalam jaringan syaraf tiruan [1]. Sementara harga daging sapi dan kambing hal ini yang dapat pembelajaran representasi itu sendiri adalah metode membuat pedagang mencampuri daging babi dengan dalam pembelajaran mesin untuk secara otomatis dalam daging lainya demi meningkatkan keuntungan. Secara mengekstrak mempelajari representasi (fitur) dari data umum tekstur dan warna daging babi, sapi dan kambing yang ada, Deep Learning telah memecahkan banyak cenderung serupa.
Karakteristik yang serupa dari ketiga jenis daging ini menyebabkan orang tidak menyadari perbedaan dari ketiga jenis daging tersebut. Kemajuan teknologi dibidang pengolahan citra digital semakin berkembang, oleh karena itu pengolahan citra digital dapat digunakan untuk mengenali dan membedakan ketiga jenis daging tersebut.

masalah seperti klasifikasi gambar [2-4], deteksi objek [5-7], pengenalan suara [8]. Penelitian tentang

Diterima Redaksi: 30-06-2021 | Selesai Revisi: 09-08-2021 | Diterbitkan Online: 20-08-2021 
klasifikasi citra babi, kambing dan sapi telah banyak Pixels dan Handphone Xiaomi Redmi Note Pro 8 dilakukan oleh beberapa peneliti diantaranya [9] dengan resolusi kamera 64 Mega Pixels pada kondisi melakukan penelitian untuk membuat model klasifikasi cahaya lingkungan pasar tradisional yang kedua dengan citra sapi dan babi dengan Grey Level Co-occurance mengunduh citra melalui Internet dari Google Images. matrix (GLCM) dan Backpropagation dengan tingkat Preprocessing data pada penelitian seperti pada alur akurasi $89 \%$ sedangkan penelitian lainnya mengenai Gambar 1.

klasifikasi jenis daging meggunakan SVM dan GLCM dengan nilai rekoknisi terbesar sebesar 87,5\%[10]. Selanjutnya penelitian yang berhubungan dengan Deep Learning yaitu Fish Recognition menggunakan VGG-16 oleh Handayani dkk [11] menggunakan arsitektur VGG16 untuk mengenali 50 jenis spesies ikan. Hasil penelitian diperoleh nilai Genuine Acceptance Rate (GAR) sebesar 96,4\%. Selain itu, Agastya et al. [12]menggunakan VGG-16 dan VGG-19 untuk mengklasifikasikan pola batik dan menemukan bahwa kinerja pengenalan meningkat $10 \%$ dengan memasukkan proses augmentasi. Penelitian tentang Deep Learning lainnya adalah, penelitian yang di lakukan oleh Rokhana et al. [13] untuk membandingkan kinerja Convolutional Neural Network (CNN) dan metode klasifikasi klasik seperti K-NN dan Support Vector Machine (SVM) untuk mendeteksi fraktur tulang paha secara otomatis dari gambar ultrasound. Hasilnya, mendapatkan hasil bahwa jaringan saraf konvolusional mengungguli metode tradisional tersebut.

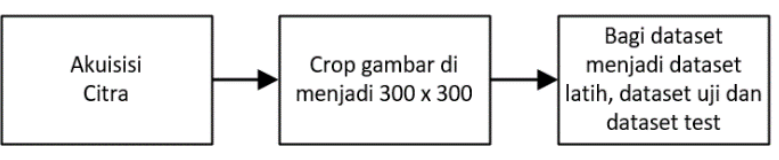

Gambar 1 Alur preprocessing data

Setelah proses akuisisi citra dilakukan, proses selanjutnya adalah melakukan cropping citra menjadi ukuran 300 x 300 pixels, hal ini dilakukan untuk mendapatkan bagian citra dan menghilangkan noise yang terdapat pada gambar seperti background yang tidak di perlukan, illustrasi proses cropping image seperti pada gambar 2.

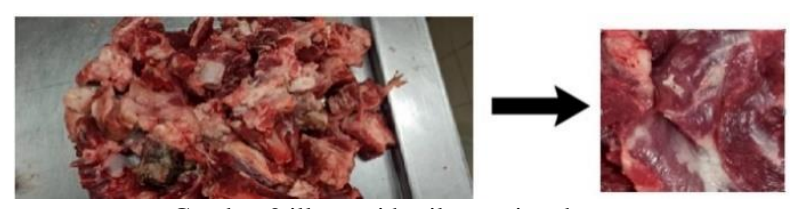

Gambar 2 illustrasi hasil cropping dataset

hasil dari cropping menghasilkan jumlah dataset sebanyak 456 buah dataset dengan rincian dataset kambing berjumlah 143 buah citra, dataset sapi berjumlah 164 buah citra dan dataset babi berjumlah 150 buah citra contoh hasil dataset yang telah di cropping dapat dilihat pada Gambar 3.

Gambar 3 adalah contoh beberapa dari citra daging yang telah melalui proses cropping, A) merupakan dataset citra daging babi, B) merupakan dataset citra daging sapi dan C) pada merupakan citra dataset daging kambing. Selanjutnya dataset yang akan di bagi menjadi 3 bagian yaitu dataset latih, dataset validasi dan dataset test hal ini dilakukan untuk malakukan evaluasi terhadap model, rincian pembagian dataset dapat dilihat pada Tabel 1 .

Tabel 1 jumlah dataset

Learning berbasis voting untuk mengenali jenis daging babi, daging kambing dan daging sapi berbasis citra, metode voting yang kami gunakan adalah Hard Voting yang merupakan keluarga Ensemble Learning. Ensemble learning adalah bidang baru dalam machine learning [16] dan Deep Learning [17-18] yang merupakan penggabungan algoritma yang berbeda untuk melatih kumpulan data dan memilih prediksi akhir berdasarkan suara terbanyak [19].

\section{Metode Penelitian}

\subsection{Pengumpulan Dataset dan Preprocessing Data}

Pengumpulan data pada penelitian ini bersumber dari 2 sumber yang berbeda yang pertama dengan akuisisi citra langsung ke pasar traditional menggunakan 2 buah alat yaitu Nikon D3200 dengan resolusi kamera 24 Mega

\begin{tabular}{llll}
\hline jenis & sapi & babi & kambing \\
\hline Dataset latih & 104 & 92 & 82 \\
Dataset validasi & 31 & 31 & 31 \\
Dataset test & 29 & 27 & 30 \\
\hline
\end{tabular}
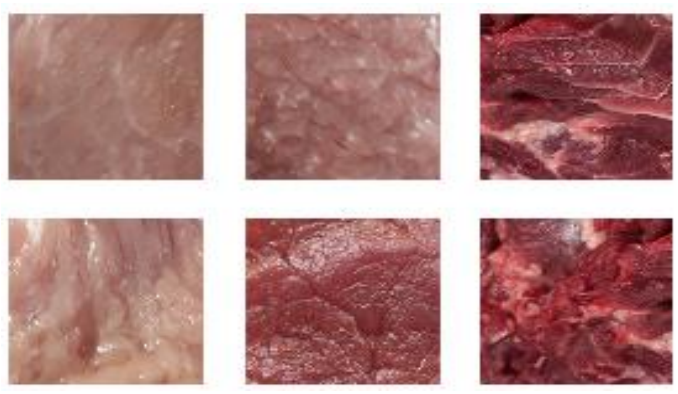

DOI: https://doi.org/10.29207/resti.v5i4.3247

Creative Commons Attribution 4.0 International License (CC BY 4.0) 

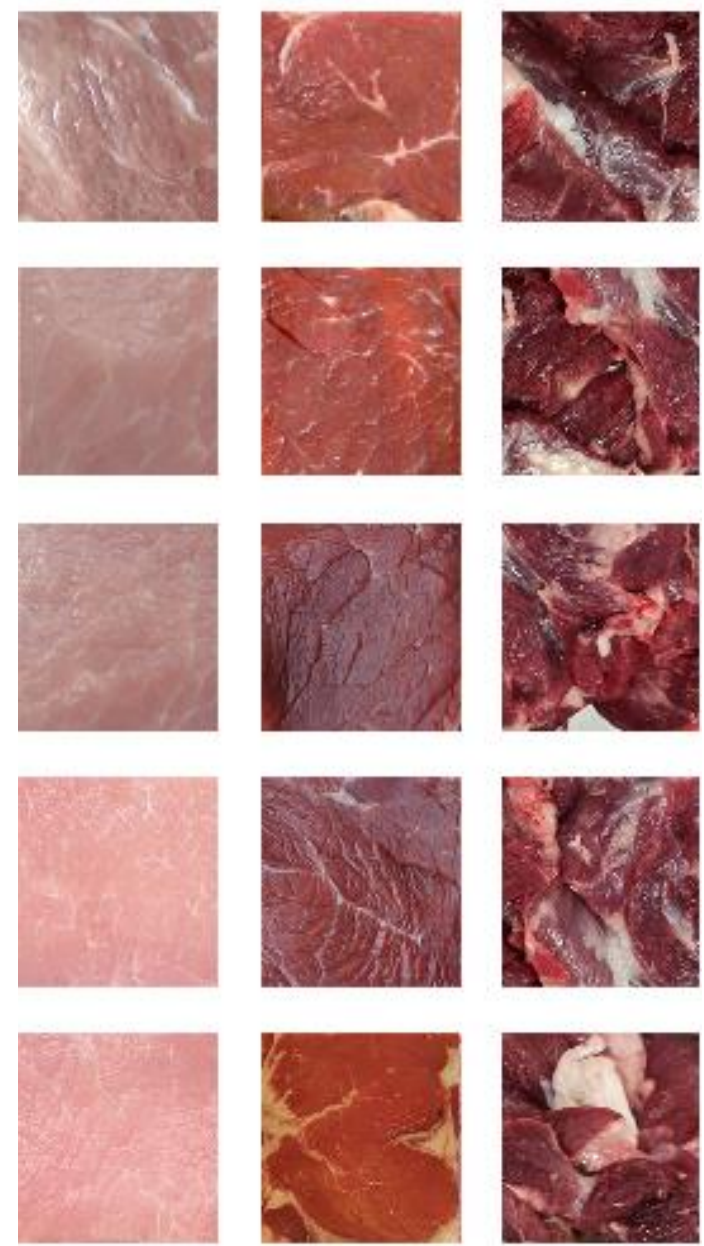

A

B

Gambar 3 contoh dataset

\subsection{Transfer Learning}

Salah satu teknik yang kami gunakan adalah transfer learning. Transfer Learning merupakan teknik transfer pengetahuan melalui Weight yang telah didapatkan dari proses latih yang dilakukan sebelumnya [20] Transfer Learning yang digunakan dalam penelitian ini menggunakan model $\mathrm{CNN}$ yang telah dilatih menggunakan data imagenet. Kami menggunakan Transfer Learning atau bisa dikatakan sebagai pretrained model karena ingin menggunakan kelebihan dari pretrained model dalam mengklasifikasikan citra babi, citra kambing dan citra sapi sehingga dapat meningkatkan performansi yang di hasilkan. Penelitian ini menggunakan 4 jenis pretrained model CNN yaitu Resnet-50, VGG-16, VGG-19 dan DenseNet-121, ke empat pretrained model tersebut akan di latih dengan beberapa skenario pelatihan dan pengujian, top layer dari ke empat pretrained model tersebut di freeze yang diubah hanya bagian fully connected layer nya saja,

\subsection{Fase latih dan fase evaluasi}

Fase latih dan fase evaluasi pada penelitian ini seperti pada Gambar 4, ke empat pretrained model akan di latih dengan hyperparameter yang telah di tentukan.

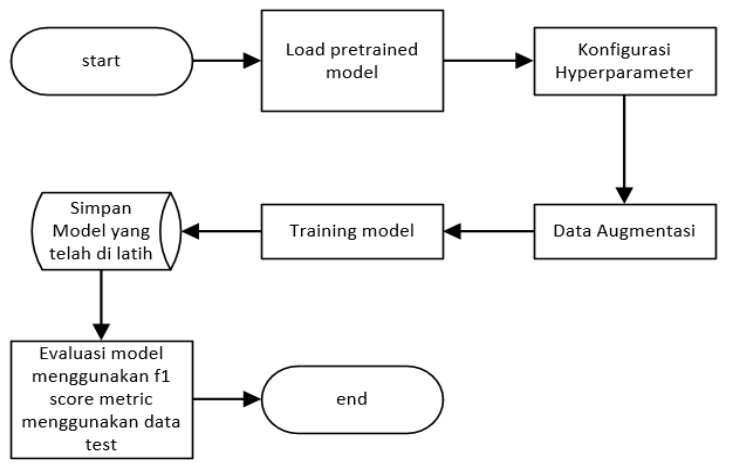

Gambar 4 Alur penelitian

Proses latih dan proses evaluasi pada penelitian ini dilakukan untuk mengetahui performance dari model terhadap hyperparameter. Hyperparameter yang digunakan pada penelitian ini berupa learning rate, momentum, epoch dan fully connected layer selain itu penelitian ini menggunakan Data Augmentation saat proses latih berlangsung. Variabel data Augmentation yang digunakan adalah zooming, shear_range dengan nilai 0.2 yang dimana nilai 0.2 tersebut merupakan nilai persenan dari citra tersebut, jika nilai zooming 0.2 maka citra akan di zooming $0.2 \%$ dari ukuran citra asli selain itu flipping image juga didgunakan pada Data Augmentation pada proses evaluasi performa dari model dilakukan setelah suatu model telah dilatih, proses evaluasi model pada penelitian ini menggunakan data test yang telah dipersiapkan ini dilakukan untuk mengetahui performa dari model tertentu terhadap citra di luar dataset latih, selain itu metric yang digunakan pada penelitian ini adalah $f 1$ score, precision dan juga recall dengan rumus 1,2 dan 3 .

$$
\begin{aligned}
& \text { Precision }(\%)=\frac{T P}{(F P+T P)} \\
& \text { Recall }(\%)=\frac{T P}{(F N+T P)} \\
& F \text {-Measure }(\%)=\frac{(2 \times \text { Recall } \times \text { Precision })}{(\text { Recall }+ \text { Precision }}
\end{aligned}
$$

perhitungan $f 1$ score, precision dan recall berdasarkan data TP, FN, FP dan TP yang didapatkan dari tabel confussion matrix. True Positive (TP) merupakan jumlah prediksi yang benar di kelas positif, sedangkan False Negative (FN) memiliki makna jumlah prediksi yang salah di kelas negatif, False Negative (FP) adalah jumlah prediksi yang salah di kelas positif sedangkan untuk True Negative (TN) memiliki arti jumlah prediksi yang benar di kelas negatif. Illustrasi confussion matrix dapat dilihat pada Gambar 5 


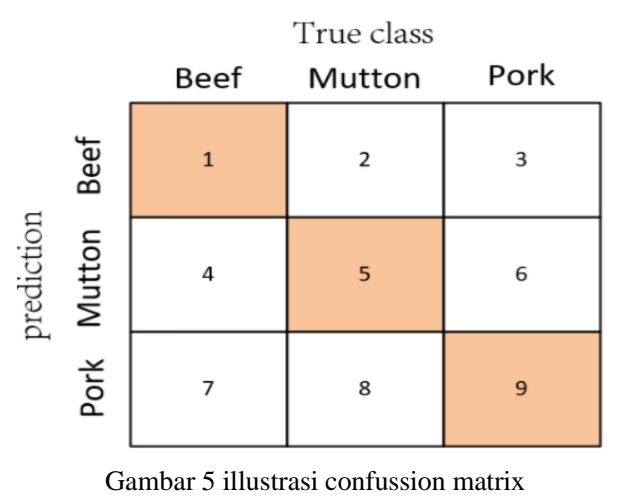

\subsection{Hard Voting Classifier}

Pada penelitian ini kami melakukan metode votingbased yaitu Hard Voting yang dimana memiliki konsep mengambil sebuah keputusan dari nilai yang terbanyak muncul [19].

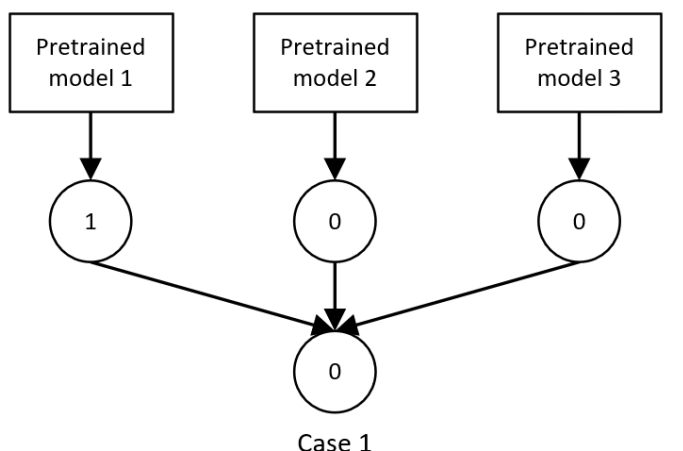

Gambar 6 Case 1

Gambar 6 merupakan illustrasi Hard Voting pada penelitian ini, pengambilan keputusan Hard Voting didasari dari suara prediksi terbanyak, jika prediksi suara terbanyak tidak ada maka model dengan performansi terbaik akan menjadi keputusan sistem Hard Voting seperti pada illustrasi case 2 seperti pada Gambar 7.

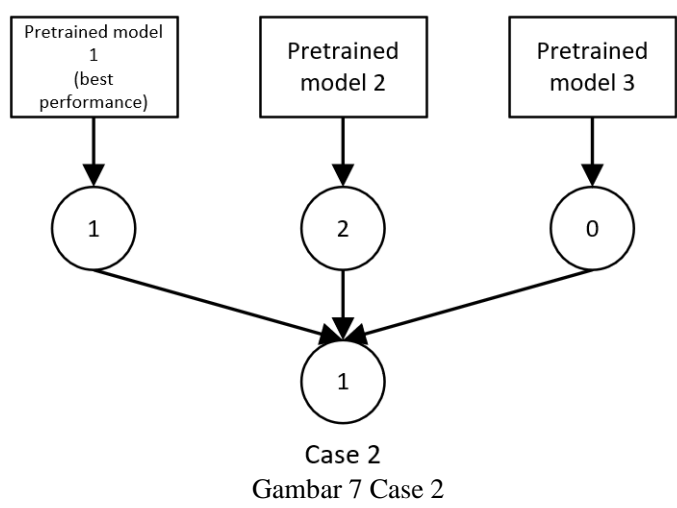

Pemilihan model arsitektur pada Hard Voting menggunakan sistem peringkat, peringkat pertama untuk model dengan kinerja terbaik sedangkan peringkat terakhir untuk model dengan kinerja terburuk. Pada penelitian ini kami membuat 2 kombinasi untuk Hard
Voting, rincian model yang digunakan pada Hard Voting seperti terlihat pada Tabel 3, hal ini kami lakukan untuk mengetahui pengaruh Hard Voting terhadap pretrained model.

Tabel 2. kombinasi pretrained model

\begin{tabular}{lllll}
\hline No & $\begin{array}{l}\text { Kombinasi } \\
\text { pertama }\end{array}$ & urutan & $\begin{array}{l}\text { Kombinasi } \\
\text { kedua }\end{array}$ & urutan \\
\hline 1 & $\begin{array}{l}\text { Pretrained } \\
\text { Model }\end{array}$ & 4 & $\begin{array}{l}\text { Pretrained } \\
\text { Model }\end{array}$ & 3 \\
2 & $\begin{array}{l}\text { Pretrained } \\
\text { Model }\end{array}$ & 3 & $\begin{array}{l}\text { Pretrained } \\
\text { Model }\end{array}$ & 2 \\
3 & $\begin{array}{l}\text { Pretrained } \\
\text { Model }\end{array}$ & 2 & $\begin{array}{l}\text { Pretrained } \\
\text { Model }\end{array}$ & 1 \\
\hline
\end{tabular}

\section{Hasil dan Pembahasan}

Hyperparameter pada pretrained model akan diganti dan di kombinasi kan beberapa kali dengan nilai yang telah di tentukan seperti pada Tabel 3, hal ini di lakukan untuk melihat dampak dan performansi dari model terhadap nilai hyperparameter yang digunakan.

Tabel 3 Hyperparameter yang digunakan

\begin{tabular}{llll}
\hline Learning rate & momentum & $\begin{array}{l}\text { Fully } \\
\text { connected } \\
\text { layer }\end{array}$ & epoch \\
\hline 0.01 & 0.9 & 3 & 50 \\
0.001 & 0.6 & $3-64$ & 75 \\
0.0001 & 0.3 & $3-64-128$ & 100 \\
\hline
\end{tabular}

Hyperparameter yang telah di tentukan akan di kombinasikan sama dengan masing-masing pretrained model agar hasilnya dapat dibandingkan pada saat evaluasi performansi dari masing-masing jenis pretrained model yang digunakan terhadap nilai suatu hyperparameter

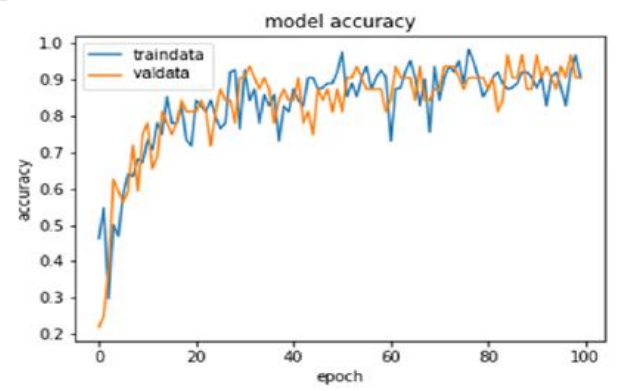

A)

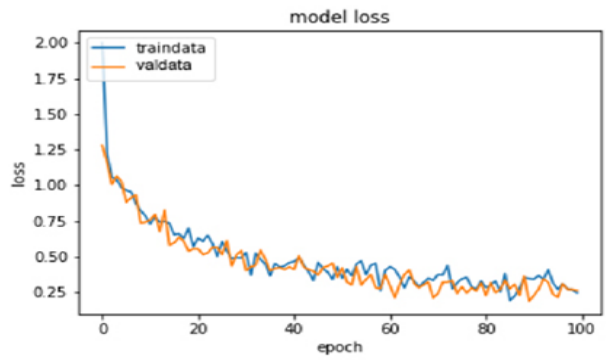

B)

Gambar 8 A) grafik performance Resnet-50 B) grafik loss Resnet-50

DOI: https://doi.org/10.29207/resti.v5i4.3247

Creative Commons Attribution 4.0 International License (CC BY 4.0) 
Gambar 8 adalah grafik performance dan grafik loss yang dimana kedua grafik tersebut merupakan grafik dari model dengan performansi terbaik yang di hasilkan oleh Resnet-50 pada saat proses latih. grafik tersebut dilatih dengan kombinasi nilai learning rate 0.01 , momentum 0.9, fully connected layer 64-3 pada epoch 100 dengan akurasi $f 1$ score sebesar $97.77 \%$, precision $97.71 \%$ dan recall $97.77 \%$

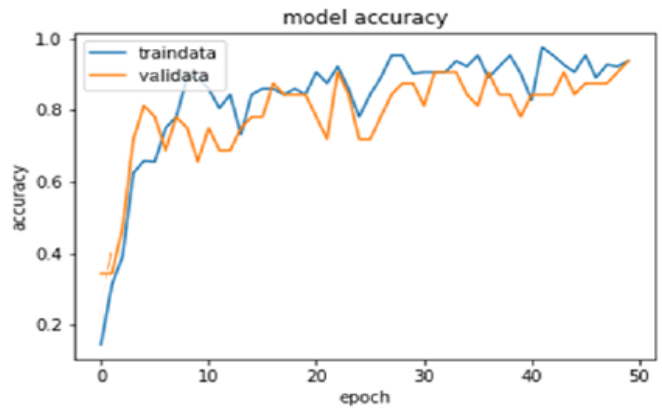

A)

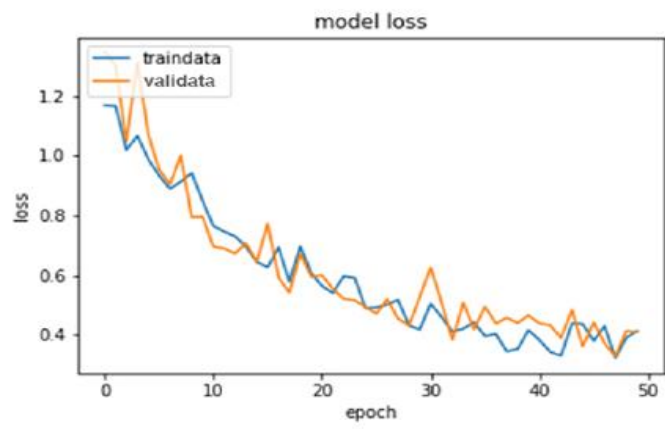

B)

Gambar 9 A) grafik performance VGG-16 B) grafik loss VGG-16

Gambar 9 merupakan grafik performance dan grafik loss dari model dengan performansi terbaik VGG-16, kedua grafik tersebut merupakan grafik hasil dengan kombinasi nilai learning rate 0.001 , momentum 0.9, fully connected layer 64-3 pada epoch 50 mendapatkan nilai fl score sebesar $95.33 \%$, precision sebesar $95.67 \%$ dan recall sebesar $94.1 \%$.

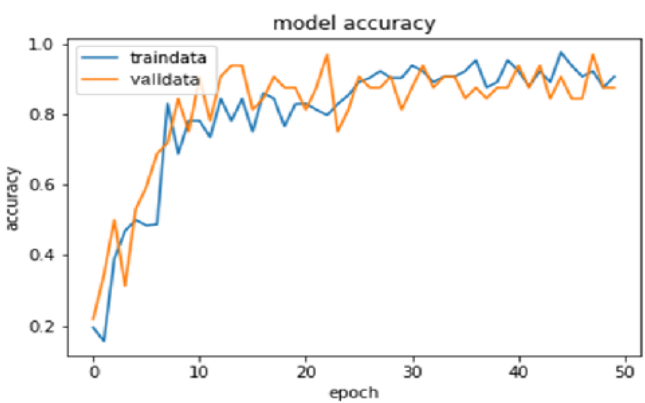

A)

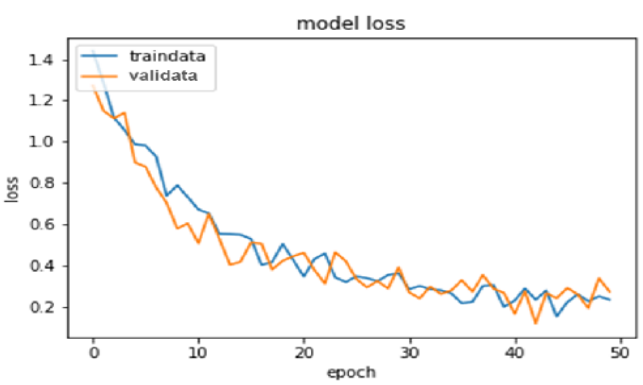

B)

Gambar 10 A) grafik performance VGG-19 B) grafik loss VGG-19

Gambar 10 terdiri dari 2 grafik yaitu grafik loss dan grafik performance pretrained model VGG-19, grafik tersebut merupakan grafik dengan performance terbaik VGG-19 dengan kombinasi learning rate 0.01, momentum 0.6, fully connected layer 64-3 pada epoch 50. Kedua grafik tersebut masih menunjukan performa model yang baik dengan memperoleh nilai fl score sebesar $94.1 \%$, precision sebesar $94.2 \%$ dan recall sebesar $94.1 \%$.

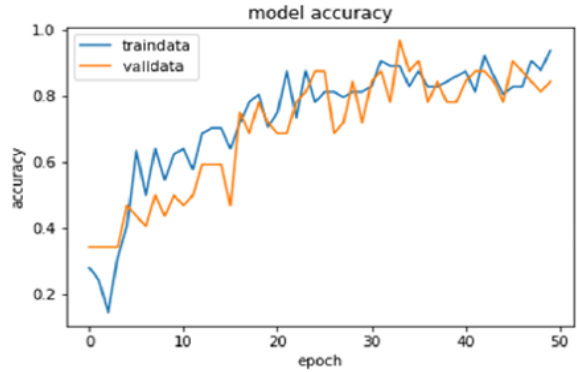

A)

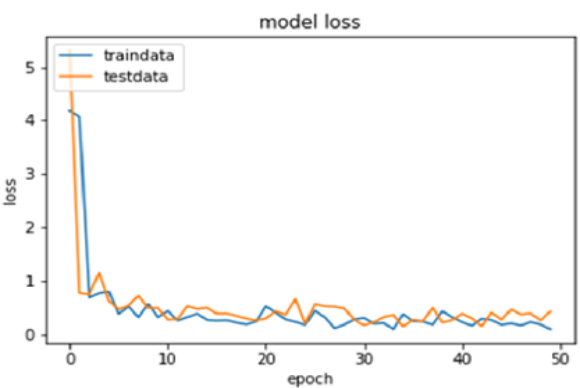

B)

Gambar 11 A) grafik performance Densenet- 121 B) grafik loss Densenet-121

Gambar 11 merupakan grafik performance dan grafik loss dari pretrained model Densenet-121 dengan performansi terbaik dengan kombinasi dengan nilai learning rate 0.01 , momentum 0.9 , fully connected layer 3 pada epoch 50 yang dapat menghasilkan nilai fl score sebesar 93\%, precision $93 \%$ dan recall $93 \%$. Rangkuman performance terbaik untuk masing-masing pretrained model dapat dilihat pada Tabel 4.

DOI: https://doi.org/10.29207/resti.v5i4.3247

Creative Commons Attribution 4.0 International License (CC BY 4.0) 
Made Bramasta Vikana Putra, I Putu Agung Bayupati

Jurnal RESTI (Rekayasa Sistem dan Teknologi Informasi) Vol. 5 No. 4 (2021) 656 - 662

Tabel 4 Rangkuman Performance Pretrained Model

\begin{tabular}{lllll}
\hline No & $\begin{array}{l}\text { Pretrained } \\
\text { Model }\end{array}$ & F1 score & Precision & Recall \\
\hline 1 & Resnet-50 & $97.77 \%$ & $97.91 \%$ & $97.77 \%$ \\
2 & VGG-16 & $95.33 \%$ & $95.67 \%$ & $95.33 \%$ \\
3 & VGG-19 & $94.1 \%$ & $94.2 \%$ & $94.1 \%$ \\
4 & Densenet-121 & $93 \%$ & $93 \%$ & $93 \%$ \\
\hline
\end{tabular}

\section{2 hasil Voting-based Deep Learning}

Hard Voting pada penelitian ini akan dicoba 2 kali dengan menggabungkan 3 model seperti terlihat pada Tabel 5.

Tabel 5 Kombinasi Voting-Based

\begin{tabular}{lllll}
\hline No & $\begin{array}{l}\text { Kombinasi } \\
\text { pertama }\end{array}$ & urutan & $\begin{array}{l}\text { Kombinasi } \\
\text { kedua }\end{array}$ & urutan \\
\hline 1 & VGG-16 & 4 & Resnet-50 & 3 \\
2 & VGG-19 & 3 & VGG-16 & 2 \\
3 & Densenet-121 & 2 & VGG-19 & 1 \\
\hline
\end{tabular}

Kombinasi pertama terdiri dari VGG-16, VGG-19, dari VGG-16, VGG-19 dan Densenet-121 dalam Densenet-121 sedangkan kombinasi kedua adalah melakukan klasifikasi citra daging.

Resnet-50, VGG-16, VGG-19 yang dimana pembagian tersebut didasari dari ururtan performansi masingmasing model. Hard Voting di evaluasi menggunakan dataset test dengan fl score metric. Hasil Hard Voting dapat dilihat pada Table 6 terlihat bahwa Hard Voting model 1 dapat mengungguli pretrained model VGG-16, VGG-19 dan Densenet-121 dengan akurasi f1 score $96,55 \%$ precision $96,56 \%$ dan recall $96,55 \%$ tetapi tidak dapat mengungguli model Resnet-50 yang telah dilatih sebelumnya dengan akurasi $f 1$ score $97,77 \%$ precision 97,91\% dan recall 97,77\%, Model Hard Voting 2 yang terdiri dari Resnet-50, VGG-16 dan VGG-19 mendapatkan akurasi yang sangat tinggi yaitu $98,88 \% \mathrm{fl}$ score, precision $98,89 \%$ dan recall $98,88 \%$ mengungguli pretrained model Resnet-50, VGG-16, VGG-19 dan juga mengungguli Hard Voting model 1, rangkuman performance voting based model dan pretrained model dapat dilihat pada Tabel 6.

Tabel 6 Hard Voting di komparasi dengan model lainya

\begin{tabular}{lllll}
\hline No & $\begin{array}{l}\text { Kombinasi } \\
\text { pertama }\end{array}$ & F1 Score & Precision & Recall \\
\hline 1 & Hard Voting-2 & $98.88 \%$ & $98.89 \%$ & $98.88 \%$ \\
2 & Resnet-50 & $97.77 \%$ & $97.91 \%$ & $97.77 \%$ \\
3 & Hard Voting -1 & $96.55 \%$ & $96.56 \%$ & $96.55 \%$ \\
4 & VGG-16 & $95.33 \%$ & $95.67 \%$ & $95.33 \%$ \\
5 & VGG-19 & $94.1 \%$ & $94.2 \%$ & $94.1 \%$ \\
6 & Densenet-121 & $93 \%$ & $93 \%$ & $93 \%$ \\
\hline
\end{tabular}

\section{Kesimpulan}

Dalam penelitian ini, kami mengklasifikasikan citra daging babi, sapi dan kambing menggunakan beberapa metode Deep Learning seperti Resnet-50, VGG-16, VGG-19 dan Densenet-121 dengan mengkombinasikan beberapa konfigurasi hyperparameter dan Hard Voting untuk mendapatkan model yang baik. Hasil tersebut kami menemukan bahwa Resnet-50 merupkan aristektur pretrained model terbaik dalam studi kasus ini dengan tingkat akurasi fl score sebesar $97,7 \%$, precision $97,91 \%$ dan recall $97,77 \%$ dengan kondisi learning rate momentum 0,01 / 0,9 pada epoch 100 dengan fully connected layer 643 node disusul oleh VGG- 16, VGG19 dan Densenet-121, selanjutnya Hard Voting 2 yang terdiri dari Resnet-50, VGG-16, VGG-19 pada studi kasus ini dapat mengungguli Hard Voting 1 dan dapat menungguli kemampuan 4 pretrained model dengan dengan akurasi f1 score $98,88 \%$, precision $98,89 \%$ dan recall 98,88\% sedangkan untuk Hard Voting 2 berada di bawah Resnet-50 dengan akurasi fl score $96,55 \%$, recall $96,56 \%$ dan precision $96,55 \%$ namun dapat mengungguli performance VGG-16, VGG19 dan Densenet-121, dari hasil evaluasi pada studi ini dapat dikatakan bahwa Hard Voting dapat meningkatkan kemampuan performance dari suatu model selain itu hasil dari studi kasus ini Resnet-50 merupakan pretrained model yang dapat mengungguli performance

\section{Daftar Rujukan}

[1] Y. LeCun, Y. Bengio, and G. Hinton, "Deep learning," Nature, vol. 521, no. 7553, pp. 436-444, 2015, doi: 10.1038 /nature 14539 .

2] P. Fischer, A. Dosovitskiy, and T. Brox, "Descriptor Matching with Convolutional Neural Networks: a Comparison to SIFT." 2015.

[3] R. Raina, A. Battle, H. Lee, B. Packer, and A. Y. Ng, "SelfTaught Learning: Transfer Learning from Unlabeled Data," in Proceedings of the 24th International Conference on Machine Learning, 2007, pp. 759-766, doi: 10.1145/1273496.1273592.

[4] S. Xia, M. Shao, J. Luo, and Y. Fu, "Understanding kin relationships in a photo," IEEE Trans. Multimed., vol. 14, no. 4 PART1, pp. 1046-1056, 2012, doi: 10.1109/TMM.2012.2187436.

[5] W. Liu et al., "SSD: Single Shot MultiBox Detector BT Computer Vision - ECCV 2016," 2016, pp. 21-37.

[6] J. Redmon, S. Divvala, R. Girshick, and A. Farhadi, "You Only Look Once: Unified, Real-Time Object Detection," in 2016 IEEE Conference on Computer Vision and Pattern Recognition (CVPR), 2016, pp. 779-788, doi: 10.1109/CVPR.2016.91.

[7] J. Redmon and A. Farhadi, "YOLO9000: Better, Faster, Stronger," in 2017 IEEE Conference on Computer Vision and Pattern Recognition (CVPR), 2017, pp. 6517-6525, doi: 10.1109/CVPR.2017.690.

[8] Y. Qian and P. C. Woodland, "Very Deep Convolutional Neural Networks for Robust Speech Recognition.” 2016.

[9] R. A. Asmara et al., "Classification of pork and beef meat images using extraction of color and texture feature by Grey Level Co-Occurrence Matrix method," IOP Conf. Ser. Mater. Sci. Eng., vol. 434, no. 1, 2018, doi: 10.1088/1757899X/434/1/012072.

[10] N. Neneng, K. Adi, and R. Isnanto, "Support Vector Machine Untuk Klasifikasi Citra Jenis Daging Berdasarkan Tekstur Menggunakan Ekstraksi Ciri Gray Level Co-Occurrence Matrices (GLCM)," J. Sist. Inf. Bisnis, vol. 6, no. 1, p. 1, 2016, doi: 10.21456/vol6iss1pp1-10.

11] P. Hridayami, I. K. G. D. Putra, and K. S. Wibawa, "Fish species recognition using VGG16 deep convolutional neural network," J. Comput. Sci. Eng., vol. 13, no. 3, pp. 124-130, 2019, doi: 10.5626/JCSE.2019.13.3.124.

[12] I. M. A. Agastya and A. Setyanto, "Classification of Indonesian Batik Using Deep Learning Techniques and Data Augmentation," in 2018 3rd International Conference on 
Made Bramasta Vikana Putra, I Putu Agung Bayupati

Jurnal RESTI (Rekayasa Sistem dan Teknologi Informasi) Vol. 5 No. 4 (2021) 656 - 662

Information Technology, Information System and Electrical Engineering (ICITISEE), 2018, pp. 27-31, doi: 10.1109/ICITISEE.2018.8720990.

[13] R. Rokhana et al., "Convolutional Neural Network untuk Pendeteksian Patah Tulang Femur pada Citra Ultrasonik BMode," J. Nas. Tek. Elektro dan Teknol. Inf., vol. 8, no. 1, p. 59, 2019, doi: 10.22146/jnteti.v8i1.491.

[14] H. Kaur and G. Kaur, "Voting based classification method for diabetes prediction," Int. J. Recent Technol. Eng., vol. 8, no. 2 Special Issue 6, pp. 913-918, 2019, doi: 10.35940/ijrte.B1172.0782S619.

[15] A. S. Assiri, S. Nazir, and S. A. Velastin, "Breast Tumor Classification Using an Ensemble Machine Learning Method," J. Imaging, vol. 6, no. 6, 2020, doi: 10.3390/JIMAGING6060039.

[16] T. G. Dietterich, "Ensemble methods in machine learning," Lect. Notes Comput. Sci. (including Subser. Lect. Notes Artif.
Intell. Lect. Notes Bioinformatics), vol. 1857 LNCS, pp. 1-15, 2000, doi: 10.1007/3-540-45014-9_1.

17] B. A. Krizhevsky, I. Sutskever, and G. E. Hinton, “Cnn实际训 练的," Commun. ACM, vol. 60, no. 6, pp. 84-90, 2012.

[18] A. Khan, A. Sohail, U. Zahoora, and A. S. Qureshi, "A survey of the recent architectures of deep convolutional neural networks," Artif. Intell. Rev., vol. 53, no. 8, pp. 5455-5516, 2020, doi: 10.1007/s10462-020-09825-6.

[19] R. Systems, "Memory-Based Weighted-Majority Prediction for Recommender Systems."

20] K. He, X. Zhang, S. Ren, and J. Sun, "Deep residual learning for image recognition," Proc. IEEE Comput. Soc. Conf. Comput. Vis. Pattern Recognit., vol. 2016-Decem, pp. 770-778, 2016, doi: 10.1109/CVPR.2016.90. 